\title{
Organisational Culture, Leadership Styles and Employee's Affective Commitment to Change: A Case of Yemen Public Sector
}

\author{
Hartini Ahmad and Hamid Mahmood Gelaidan \\ College of Business, Universiti Utara Malaysia, Malaysia
}

\begin{abstract}
The purpose of this study is to examine the effect of leadership style on the affective commitment to change, moderated by the organisational culture. The research adopts both qualitative and quantitative approaches through a survey with 371 employees of public organisations in Yemen, as well as interviews with the managers. The findings showed that the transformational leadership was positively related to the employee's affective commitment to change; similar to the transactional leadership that was positively related to the affective commitment to change. The results showed that organisational culture had positively moderated the relationship between the leadership styles and employee affective commitment to change. Finally, the findings revealed that the transactional leadership was a strong predictor to affective commitment to change compared with the transformational leadership.
\end{abstract}

Keywords: Leadership, commitment to change, organisational culture, Yemen

\section{Introduction}

Nowadays, change management is becoming a well known phenomenon. Obviously, change is the only constant that happens on a continuous basis (Probst \& Raisch, 2005). Though many change efforts were carriedout by most of the organisations, there is a misunderstanding concerning the needs of change that have precipitated in many failed change initiatives and wasted the organisations' time, money and other resources (Burke, 2002; Kotter, 1995; Probst \& Raisch, 2005).

Previous researches on organisational change focused on variety of aspects such as leadership (Kotter, 1995), communication
(Schweiger \& Denisi, 1991) procedural fairness (Brockner, 2002) and layoffs and turnover (Paterson, Green, \& Cary, 2002), nevertheless there has been a lack of focus on individual commitment to change. Therefore, one of the many reasons why change efforts failed lies in the people and their inadequate or lack of commitment to change. The commitment to change comes from the people in the organisation.

Observing the importance of change, the Yemeni government has continuously enforced many developments and changes to the public organisations. One of the change initiatives in the public organisations is financial and administrative reform in 1997, followed by several transformations since

Copyright (C) 2011 Hartini Ahmad and Hamid Mahmood Gelaidan. This is an open access article distributed under the Creative Commons Attribution License unported 3.0, which permits unrestricted use, distribution, and reproduction in any medium, provided that original work is properly cited. Contact author: Hartini Ahmad e-maill: hartini@uum.edu.my 
the past fourteen years. Like other transformation efforts, there are many challenges along the way of changes in order to reach the desired outcomes. It is realised that one of the most obstacles is the lack of commitment to change, and also leadership styles and skills (Elias, 2009; Jalil, 2011).

In order to minimise such problem, the current researcher observes the commitment to change from the people in the organisation, more likely to lead to a smooth change. This view is supported by previous studies such as Shum, Bove, and Seigyoung (2008) and Svensen, Neset, and Eriksen (2007). Furthermore, Elias (2009) stressed that the failure of change mostly came from human aspect comprehensively, including both leaders' and followers' aspects. Therefore, this study investigates the relationship between the leadership styles and employee affective commitment to change.

\section{Research Questions and Hypotheses}

This intention of the study is mainly due to the following research questions:

1. Does transformational leadership style associate with employee's affective commitment to change?

2. Does transactional leadership style associate with employee's affective commitment to change?

3. Does the organisational culture alter the relationship between the leadership styles (transformational and transactional) and the employee's affective commitment to change?

Furthermore, the following hypotheses were developed:

$\mathrm{H}_{1}$. There is a positive relationship between transformational leadership and employee's affective commitment to change
$\mathrm{H}_{2}$. There is a negative relationship between transactional leadership and employee's affective commitment to change

$\mathrm{H}_{3}$. Organisational culture moderates the relationship between leadership styles (transformational and transactional) and employee's affective commitment to change.

\section{Literature Review}

\section{Organisational Change}

Organisational change can be categorised in many forms either in macro or micro perspectives. Nadler and Tushman (1990) indicated that there are several types of changes which can occur in the organisations, in terms of shifts in industry structure; products entering the maturation or decline phases of their life cycles; technological innovations; macroeconomic trends and crises; regulatory or legal changes; market or competitive forces; or growth. He also indicated that organisations have to respond fast to the change by increasing customer value, enhancing innovation, engaging employees and obtaining true competitive advantage. Furthermore, Cummings and Worley (2005) indicated that organisations have to respond quickly to changing environmental forces in order to survive and thrive in this rapidly changing market. Therefore, change should be seen as inevitable to the organisation, however it needs to be managed to ensure the success of its implementation.

Furthermore, as the organisational change should not be treated as in isolation, CowanSahadath (2010) stated that successful organisational change requires the organisation to align its corporate strategies; corporate objectives, culture, performance and leadership to be dynamic and responsive. It should be noted that successful changes are linked to these elements in an integrative way. The Most crucial element is also the people; 
consequently, we observe that a successful organisation change requires reciprocal from the people (leader-follower) as the main factor. This is because of the fact that if it has been accepted by the people, the chances for a successful implementation will be higher. On the other hand, the resistance to change; the change is more likely to fail though there are good planning and strategy alignment (for example: Cowan-Sahadath, 2010; Cummings \& Worley, 2005).

\section{Commitment to Change}

Porter, Steers, Mowday, and Boulian (1974) defined organisational commitment as "the relative strength of an individual's identification with and involvement in a particular organisation." Organisational commitment can be divided into two concepts; behaviour and attitude (Johnston, Parasuraman, Furell, \& Black, 1990). In one viewpoint, commitment is viewed as "primarily as a function of individual behaviour and individuals are postulated to become committed to the organisation through their actions and choices over time." Another viewpoint says that commitment "is thought to develop when people begin to identify with an organisation and are willing to exert effort towards organisational goals and values. Declared in a different way, commitment is viewed as a more active and positive attitude towards the organisation" (Johnston, et al., 1990). In another way, Mowday, Steers, and Porter (1979) indicated that, organisational commitment as an emotional addition to an organisation, within sharing values, prefers to stay with the organisation as well as being enthusiastic to exert extra effort in order to achieve the organisation goal.

Meyer and Herscovitch (2001) argued that the "core essence" of commitment should be the same regardless of the target of that commitment. Based on a review of existing definitions, they suggested that commitment, in general, could be defined as "a force that binds an individual to a course of action of relevance to one or more targets." Explaining further, they said "a force that binds an individual to this course of action can reflect (i) a desire to provide support for the change based on a belief in its inherent benefits (affective commitment to change), (ii) a recognition that there are costs associated with failure to provide support for the change (continuance commitment to change), and (iii) a sense of obligation to provide support for the change (normative commitment to change). In order to simplify the different kinds of commitment to change, Herscovitch and Meyer (2002) stated that employees can feel bound to support a change because they (want to), (have to), and/or (ought to).

\section{Leadership Style}

Burns (1978) was one of the first to research transactional and transformational leadership. Transformational leadership has been defined as "the process of influencing major changes in the attitudes and assumptions of organisation members and building commitment for the organisation's mission or objectives" (Yukl, 1989, p.204). Since 1980s, a body of theoretical work has been developing on the role of transformational leadership in affecting change (Bass, 1985). Other dominant theories of transformational leadership and transactional leadership refer mainly to the relationship between supervisors and subordinates in their day-to-day activities (e.g. how this type of leader affects his followers by motivation and satisfaction), but are not necessarily concerned with leadership as they relate to change or specifically how leaders affect change in people (House, 1996). Ahmad, Francis, \& Zairi (2007) found that the different styles of leadership lead to different results, and drastic change required more autocratic style. The following section elaborates the two dominant styles of leadership more, namely; the transformational and transactional leadership. 


\section{Transformational Leadership}

The category to which the theory of transformational leadership belongs has been referred as "neo charismatic theory" (House \& Aditya, 1997) or "the new leadership theories" (Bryman, 1993). House and Aditya (1997) described four ordinary characteristics of these theories; firstly, the achievement of exceptional performance by leaders. Secondly, certain leaders can induce high levels of motivation, trust and commitment among followers. Thirdly, some leaders demonstrated symbolic or emotional aspects to appeal. Finally, leader's vision influenced followers such as increasing their self-esteem, motivation and identification. Based on previous studies such as Bass and Avolio (1994), transformational leadership has four concepts which are as follows: idealized influence leadership, inspirational motivation, intellectual stimulation and individualized consideration. Furthermore, Yu, Leithwood, and Jantzi (2002) found a significant effect of transformational leadership on commitment to organisational change. In earlier stage, that is the sense of urgency, transformational leadership is significant to ensure the buy-in among the employees (Jalil, 2011).

\section{Transactional Leadership}

Bass (1985) indicated that transactional leaders prefer operating within the current system or culture, tend to avoid risk and rely on organisational rewards and punishments to motivate employee performance. He describes transactional leaders as costbenefit oriented, where they focus on rewarding efforts and ensuring that behaviours are up to expectations (Bass \& Avolio, 1993). Transactional leadership behaviours include three factors in the Multi-Factor Leadership Questionnaire (MLQ). The first factor is contingent reward, which refers to a swap agreement between leader and follower. The other two factors are active and passive management by exception. These are corrective leadership behaviour. While in the dynamic form, the leader actively monitors subordinates' performance and corrects any mistakes, in the passive form, the leader does not monitor but waits for mistakes to happen and then takes action. The employee can still be engaged with the change implementation not because they want to but because they have to, also supported by Ahmad et al. (2007). In this situation, transactional leadership is expected to be associated with employee commitment to organisational change.

\section{Organisational Culture}

Peters and Waterman (1982) suggested that organisational culture has a considerable influence on organisations, particularly in areas such as commitment. Maintaining commitment during the uncertainty that is associated with the transition period is very important because it changes an internal part of organisational culture (Narine \& Persaud, 2003). Furthermore, (Porter, et al., 1974) argued that organisational commitment starts with a firm belief in the acceptance of the organisation's goal and values and additionally the authors suggested that the internalization of organisational values should create a strong belief in these values, consequently creating a perception of individual commitment to the organisation. Likewise, Ritchie (2000) mentioned that commitment is an essential outcome of internalization, as it helps ensure a stable population that is likely to maintain and continue the culture and further to that, it was found that employees with a positive predilection and belief about change will enhance a firm's capability to change (Lau, Tse, \& Zhou, 2002; Tripsas \& Gavetti, 2000). Schimmoeller (2010) stressed the connection between the different styles of leadership and organisational culture. The leaders influence employees to be involved in the change and work together to meet the objectives. 


\section{Research Design and Methodology}

The study was conducted using both quantitative and qualitative approaches. The survey developed based on previous studies (Bass \& Avolio, 2004; Glaser, Zamanou, \& Hacker, 1987; Herscovitch \& Meyer, 2002; Schrodt, 2002). This survey was divided into three sections, the first section was the demographic factors, the second section was on the change profile and the final section was on the key factors, which were: a) employee commitment to change; b) transformational and transactional leadership; c) organisational culture.

The questionnaire contained five-point Likert scales, which anchored at " 1 "= Strongly Disagree to " 5 "=Strongly Agree, specific to measure the "employee commitment to change" and "organisational culture". Whereas, " 1 "=Not at All, ' 2 "=0nce in a While, " 3 "=Sometimes, "4"=Fairly Often, “ 5 '=Frequently if not Always, were used for the "leadership style". Table 1 shows the measurements of each variable in the questionnaire.

Table 1. Summary of Variables, Dimensions and Total Number of Items

\begin{tabular}{|l|l|c|}
\hline Variable & Dimensions & Total number of items \\
\hline $\begin{array}{l}\text { Employee commitment to } \\
\text { change }\end{array}$ & Affective commitment to change & 6 \\
Herscovitch and Meyer & & \\
(2002) & & 8 \\
\hline Transformational leadership & Idealized influence & 4 \\
Bass, B.M. \& Avolio, B.J. & Inspirational Motivation & 5 \\
(2004) & Intellectual Stimulation & 3 \\
\hline Transactional leadership & Individualized Consideration & 4 \\
Bass, B.M. \& Avolio, B.J. & Contingent Reward & 4 \\
(2004) & Management by exception & 4 \\
& passive & \\
\hline Organisational culture & Management by exception active & 9 \\
Glaser, Zamanou and Hacker & Team work & 6 \\
(1987) & Climate Atmosphere & 4 \\
& Communication Information flow & 4 \\
& Involvement & 7 \\
\hline
\end{tabular}

The population of this study was the public sector organisation in Yemen. A number of 371 employees from public sectors of Yemen (4) responded to the study. The multiple regressions, which were then narrowing to the hierarchical regressions, were conducted to test the hypotheses.

In term of qualitative, interview was conducted with respective managers in order to enhance the results of survey findings. The information gathered from the interviews were categorised into the relevant factors.

\section{Results}

The section reports the survey and interview findings relevant to the three research objectives. Table 2 shows the results of the relationship between transformational leadership and employee affective commitment to change, with moderating variable of organisational culture (Research Objective 1). 
Table 2. Model Summary Transformational Leadership, Organisational Culture, and Affective Commitment to Change

\begin{tabular}{|c|c|c|c|c|c|c|c|c|c|}
\hline \multirow[t]{2}{*}{ Model } & \multirow[b]{2}{*}{$\mathbf{R}$} & \multirow[b]{2}{*}{$\begin{array}{c}\mathrm{R} \\
\text { Square }\end{array}$} & \multirow[b]{2}{*}{$\begin{array}{c}\text { Adjusted R } \\
\text { Square }\end{array}$} & \multirow[b]{2}{*}{$\begin{array}{l}\text { Std. Error of } \\
\text { the Estimate }\end{array}$} & \multicolumn{5}{|c|}{ Change Statistics } \\
\hline & & & & & $\begin{array}{l}\text { R Square } \\
\text { Change }\end{array}$ & $\begin{array}{c}\mathrm{F} \\
\text { Change }\end{array}$ & df1 & df2 & $\begin{array}{c}\text { Sig. F } \\
\text { Change }\end{array}$ \\
\hline 1 & $.538^{\mathrm{a}}$ & .290 & .288 & .56817 & .290 & 150.689 & 1 & 369 & .000 \\
\hline 2 & $.790^{\mathrm{b}}$ & .624 & .622 & .41401 & .334 & 326.974 & & 368 & .000 \\
\hline
\end{tabular}

a. Predictors: (Constant), Transformational

b. Predictors: (Constant), Transformational, Transformational*Culture

c. Dependent Variable: Affective Commitment to Change

The first model explained that the effect of transformational leadership on employee affective commitment to change, which is the $\mathrm{R}^{2}$ was .290, indicated that transformational leadership explains about 29 percent of variance of employee affective commitment to change. In the other hand, the second model explains the moderating effect of the organisational culture on the relationship between the transformation leadership and employee affective commitment to change. The $\mathrm{R}^{2}$ was .624, which explains about 62 percent of the contingent effect of the organisational culture on the relationship between the transformational leadership and affective commitment to change.

Table 3 shows the effect of transactional leadership on employee affective commitment to change, and the moderating effect of organisational culture on the relationship between the transactional leadership and employee affective commitment to change.

Table 3. Model Summary Transactional Leadership, Organisational Culture, and Affective Commitment to Change

\begin{tabular}{|c|c|c|c|c|c|c|c|c|c|}
\hline \multirow[t]{2}{*}{ Model } & \multirow[b]{2}{*}{$\mathrm{R}$} & \multirow[b]{2}{*}{$\begin{array}{c}\mathrm{R} \\
\text { Square }\end{array}$} & \multirow[b]{2}{*}{$\begin{array}{l}\text { Adjusted R } \\
\text { Square }\end{array}$} & \multirow[b]{2}{*}{$\begin{array}{l}\text { Std. Error of } \\
\text { the Estimate }\end{array}$} & \multicolumn{5}{|c|}{ Change Statistics } \\
\hline & & & & & $\begin{array}{l}\text { R Square } \\
\text { Change }\end{array}$ & $\begin{array}{c}\mathrm{F} \\
\text { Change }\end{array}$ & df1 & df2 & $\begin{array}{c}\text { Sig. F } \\
\text { Change }\end{array}$ \\
\hline dimencion 1 & $.596^{\mathrm{a}}$ & .355 & .353 & .54156 & .355 & 203.021 & & 369 & .000 \\
\hline 2 & $.779 \mathrm{~b}$ & .607 & .605 & .42344 & .252 & 235.594 & & 368 & .000 \\
\hline
\end{tabular}

a. Predictors: (Constant), Transactional

b. Predictors: (Constant), Transactional, Transactional*Culture

c. Dependent Variable: Affective Commitment to Change

The first model explains the association of the transactional leadership and employee affective commitment to change, which the transactional leadership explains about 35 percent of variance of employee affective commitment to change. The transactional leadership had positive relationship with employee affective commitment to change.

The second model explains the moderating effect of organisational culture on the relationship between the transactional leadership and employee affective commitment to change, which explains about 60 percent of variance of the relationship between the specific variables.

This section has disclosed the result from the in-depth interview with participants in order to explain the relationship between the leadership style and employee affective commitment to change and also their relation through the organisational culture as moderating. The elaboration for this interview which presents the descriptions of the qualitative findings is shown in Table 4. 
Table 4. Description Table of the Qualitative Findings

\begin{tabular}{|c|c|c|}
\hline $\begin{array}{l}\text { Theme } \\
\text { and } \\
\text { Category }\end{array}$ & Factor & Description \\
\hline Leadership & Leaders style & $\begin{array}{l}\text { Close relationship between management and } \\
\text { employees is important to ensure the commitment to } \\
\text { change. } \\
\text { Human oriented more suited when the followers are } \\
\text { well educated, and have sufficient work experiences. } \\
\text { To achieve fast and quick results, employee needs to be } \\
\text { communicated clearly on the expected contribution. } \\
\text { Leaders who focused more on task and achieving the } \\
\text { objective. Transactional leadership style found better } \\
\text { to get commitment for change for shorter term } \\
\text { compared to transformational leadership, which more } \\
\text { appropriate for long term results. }\end{array}$ \\
\hline \multirow[t]{3}{*}{$\begin{array}{l}\text { Organisati } \\
\text { onal } \\
\text { Culture }\end{array}$} & Shared values & $\begin{array}{l}\text { Still there is no standard norms were followed by each } \\
\text { and every individual in the organisations. However, } \\
\text { employees show commitment is they know the } \\
\text { direction clearly and know what the expectation from } \\
\text { the leader is. }\end{array}$ \\
\hline & Information flow & $\begin{array}{l}\text { Leader who communicates effectively can recognize } \\
\text { how to deal with the employee in enhancing their } \\
\text { commitment to the change. }\end{array}$ \\
\hline & Cooperation & $\begin{array}{l}\text { Collaboration between the leaders and subordinate } \\
\text { provide effectiveness achievement and smoothly } \\
\text { successful change. }\end{array}$ \\
\hline
\end{tabular}

\section{Discussions}

Leadership style is thought to be very important in term of change because of the ability of leadership style to guide the employee and motivate them to be committed to that change. Thus, in this study, we assumed that transformational leadership style has a positive impact on employee affective commitment to change as first assumption, the second hypothesis is that transactional leadership has a negative impact on the employee affective commitment to change, the final hypothesise is assuming that organisational culture creates a positive moderating relationship between the leadership style (transformational \& transactional) and employee affective commitment to change with regard to this study conducted in Yemen public sector.

Using multiple regressions and hierarchical regression, we found that transformational leadership were positively significant related to employee affective commitment to change in the same line with other findings (Herold, Fedor, Caldwell, \& Liu, 2008) which found that transformational leadership were positively related to employee commitment to change.

Furthermore, it was not proven that the transactional leadership were negatively 
significant related with affective commitment to change. However, the similar findings were found in Lo, Ramayah, \& Run, (2010) that transactional leadership is more able to achieve employee commitment to change than transformational leadership. As validated in the qualitative finding which showed that the employee may need some consideration to form the leader. In addition, it can be seen that the transformational leadership needs some emphasis in order to have high impact among the employee. It also showed that the more the leader shares or facilities the change, the more commitment they will get from the employees. Furthermore, surprisingly, most of the employees in Yemen prefer to work in a more transactional style management as this is related to their behaviours and norms.

Without doubt, organisational culture is playing an important role of moderating the effect of leadership style and employee affective commitment to change. The result shows that organisational culture was positively significant moderating the relationship between both transformational and transactional leadership styles, and employee affective commitment to change. This is because employees need clear objectives and expectations from the leaders to embrace the change.

\section{Implications}

Several implications will be highlighted from these study findings. Firstly, this study provides the theoretical empirical research regarding the leadership style, organisational culture and employee affective commitment to change in the public sector. Despite that, we know that leadership style is an important factor as an essential condition for the effective use of commitment to change, but there is a lack of empirical studies on leadership style, organisational culture, and employee affective commitment to change in general and especially the public sector. With respect to previous studies in this matter, but they are limited in terms of their ability to provide clear guideline and to choose which is the appropriate leadership style to implant successful change and to achieve high commitment. It is believed that this study has added value to the literatures on public sector leadership style especially in the Yemen context since there were limited literatures done on a similar setting.

\section{Limitations and Conclusion}

The paper highlights several limitations. First, the study focused on the public sector, future studies can be conducted in private sector or other types of industry. Second, data collection was done cross-sectional; therefore, future studies may look into longitudinal study in order to expand the findings that are the pre- and post-change. Finally, this model is not comprehensive, other studies may require and include all dimensions of employee commitment to change, and other factors are recommended to replicate the study in different contexts. In conclusion, leadership and organisational change are very important fields of study for both researchers and practitioners; therefore this study has proven the importance of the investigation of these two areas.

\section{Acknowledgment}

We are grateful to the Almighty Allah for giving us strength to complete the study. May peace and blessing of Allah be upon His beloved Prophet Muhammad (SAW), his family and his companions. We owe a debt of gratitude and thanks to all the respondents and participants of this study who gave us their support and commitment.

\section{References}

Ahmad, H., Francis, A. \& Zairi, M. (2007). "Business Process Reengineering: Critical Success Factors in Higher Education," Business Process Management Journal, 13(3). 451-469.

Bass, B. M. (1985). "Leadership: Good, Better, Best," Organisational Dynamics, 13(3). 26-40. 
Bass, B. M. \& Avolio, B. J. (1993). 'Transformational Leadership and Organisational Culture,' Public Administration Quarterly, 17(1). 112-121.

Bass, B. M. \& Avolio, B. J. (1994). 'Improving Organisational Effectiveness through Transformational Leadership,' Sage Publications, New Jersey.

Bass, B. M. \& Avolio, B. J. (2004). 'Multifactor Leadership Questionnaire (MLQ),' Mind Garden, New Jersey.

Brockner, J. (2002). "Making Sense of Procedural Fairness: How High Procedural Fairness Can Reduce or Heighten The Influence of Outcome Favorability," Academy of Management Review, 27(1). 58-76.

Bryman, A. (1993). "Charismatic Leadership In Business Organisations: Some Neglected Issues," The Leadership Quarterly, 4(3-4). 289-304.

Burke, W. W. (2002). 'Organisation Change: Theory and Practice,' Sage Publications, New Jersey.

Burns, J. M. G. (1978). 'Leadership: Harper \& Row,' New York.

Cowan-Sahadath, K. (2010). "Business Transformation: Leadership, Integration And Innovation-A Case Study," International Journal of Project Management, 28(4). 395404.

Cummings, T. G. \& Worley, C. G. (2005). 'Organisation Development and Change,' Mason: South-Western/Thomson, London.

Elias, S. M. (2009). "Employee Commitment in Times of Change: Assessing the Importance of Attitudes Toward Organisational Change," Journal of Management, 35(1). 37-55.

Glaser, S. R., Zamanou, S. \& Hacker, K. (1987). 'Measuring and Interpreting Organisational Culture,' Management Communication Quarterly : McQ (1986-1998). 1(2). 173.
Herold, D. M., Fedor, D. B., Caldwell, S. \& Liu, Y. (2008). "The Effects of Transformational and Change Leadership on Employees' Commitment to a Change: A Multilevel Study," Journal of Applied Psychology, 93(2). 346-357.

Herscovitch, L. \& Meyer, J. P. (2002). "Commitment to Organisational Change: Extension of aThree-Component Model," Journal of Applied Psychology, 87(3). 474487.

House, R. J. (1996). "Path-Goal Theory of Leadership: Lessons, Legacy, and a Reformulated Theory," Leadership Quarterly, Fall, 323.

House, R. J. \& Aditya, R. N. (1997). "The Social Scientific Study of Leadership: Quo Vadis?," Journal of Management, 23(3). 409.

Jalil, J. (2011).'The Relationship Between Personality Traits, Internal Communication, Transformational Leadership and Sense of Urgency: A Mixed Method Study of Repso Malaysia,' DBA Dissertaion. Universiti Utara Malaysia.

Johnston, M. W., Parasuraman, A., Furell, C. M. \& Black, W. C. (1990). "A Longitudinal Assessment of the Impact of Selected Organisational Influences on Salespeople's Organisational Commitment During Early Employment," Journal of Marketing Research (JMR). 27(3). 333-344.

Kotter, J. P. (1995). "Leading Change: Why Transformation Efforts Fail," Harvard Business Review, 73(2). 59-67.

Lau, C.-M., Tse, D. K. \& Zhou, N. (2002). "Institutional Forces And Organisational Culture In China: Effects On Change Schemas, Firm Commitment And Job Satisfaction," Journal of International Business Studies, 33(3). 533-550.

Lo, M.-C., Ramayah, T. \& Run, E. C. (2010). "Does Transformational Leadership Style Foster Commitment to Change? The Case of Higher Education in Malaysia," Procedia - 
Social and Behavioral Sciences, 2(2). 53845388.

Meyer, J. P. \& Herscovitch, L. (2001). "Commitment in the Workplace: Toward a General Model," Human Resource Management Review, 11(3). 299.

Mowday, R. T., Steers, R. M. \& Porter, L. W. (1979). "The Measurement of Organisational Commitment," Journal of Vocational Behavior, 14(2). 224-247.

Nadler, D. A. \& Tushman, M. L. (1990). "Beyond the Charismatic Leader: Leadership and Organisational Change," California Management Review, 32(2). 77-97.

Narine, L. \& Persaud, D. D. (2003). "Gaining and Maintaining Commitment to Large-Scale Change in Healthcare Organisations," Health Services Management Research, 16(3). 179187.

Paterson, J. M., Green, A. \& Cary, J. (2002). "The Measurement of Organisational Justice in Organisational Change Programmes: A Reliability, Validity and Context-Sensitivity Assessment," Journal of Occupational \& Organisational Psychology, 75(4). 393-408.

Peters, T. \& Waterman, R. (1982). 'In Search of Excellence,' Lessons From America's BestRunning Companies, HarperCollins, New York.

Porter, L. W., Steers, R. M., Mowday, R. T. \& Boulian, P. V. (1974). "Organisational Commitment, Job Satisfaction, and Turnover among Psychiatric Technicians," Journal of Applied Psychology, 59(5). 603-609.

Probst, G. \& Raisch, S. (2005). "Organisational Crisis: The Logic of Failure," Academy of Management Executive, 19(1). 90-105.

Schimmoeller, L. J. (2010). "Leadership Styles in Competing Organisational Cultures," Leadership Review, 10(2). 125 -141.

Schrodt, P. (2002). "The Relationship Between Organisational Identification and
Organisational Culture: Employee Perceptions of Culture and Identification in a Retail Sales Organisation," Communication Studies, 53(2). 189.

Schweiger, D. M. \& Denisi, A. S. (1991). "Communication with Employees Following a Merger: A Longitudinal Field Experiment," Academy of Management Journal, 34(1). 110135.

Shum, P., Bove, L. \& Auh, S. (2008). "Employees' Affective Commitment to Change the Key to Successful CRM Implementation," European Journal of Marketing, 42(11/12). 1346-1371.

Svensen, E., Neset, G. \& Eriksen, H. R. (2007). "Factors Associated with a Positive Attitude towards Change among Employees During the Early Phase of a Downsizing Process," Scandinavian Journal of Psychology, 48(2). 153-159.

Tripsas, M. \& Gavetti, G. (2000). "Capabilities, Cognition, and Inertia: Evidence from Digital Imaging," Strategic Management Journal, 21(10/11). 1147.

Yu, H., Leithwood, K. \& Jantzi, D. (2002). "The Effects of Transformational Leadership on Teachers' Commitment to Change in Hong Kong," Journal of Educational Administration, $40(4 / 5) .368$.

Yukl, G. (1989). "Managerial Leadership: A Review of Theory aand Research," Journal of Management, 15(2). 213-252. 